\title{
Utilization of Federal Reserve Bank Services by Member Banks: Implications for the Costs and Benefits of Membership
}

\author{
R. ALTON GILBERT
}

HE proportion of commercial banks belonging to the Federal Reserve System has been declining for more than three decades. The percentage of banks in the Federal Reserve System decreased from 49.1 percent of all commercial banks in 1945 to 39.3 percent at the end of 1976 (see Chart I). The percentage of total bank deposits held at Federal Reserve member banks declined from 86.3 percent to 73.8 percent over the same period.

The reason banks mention most frequently for withdrawing from Federal Reserve membership is the cost of reserve requirements imposed on members relative to reserve requirements of the various states for nonmember banks. ${ }^{1}$ However, the utilization of Federal Reserve Bank services by member banks must also be considered in an analysis of the costs and benefits of membership. The implications for the costs and benefits of Federal Reserve membership are analyzed on the basis of a survey of services used by member banks that are served by the head office of this Reserve Bank.

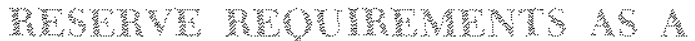

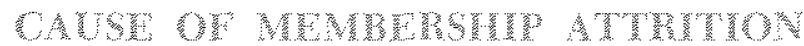

In general, state reserve requirements for nonmembers are not lower than those for member banks.2 This observation is especially applicable to smaller banks, since in about half of the states reserve requirements are flat percentages of various classes of

Peter Rose, "Exodus: Why Banks are Leaving the Fed," The Banker: Magazine (Winter 1976), pp. 43-49.

"Required subscriptions to Fefteral Reserve Bank stock by member banks car be considered a type of interest beaning reserve requirement. Member banks must subscribe to stock of their Federal Reserve Banks in amounts proportional to their capital and surplns. The ammal yicld on that stock is six percent. That rate of return was a sigrificant indecement to membership in the 1930 s and 1940 , when market interest rates were very low, but given the market interest rates of recent years, the yield on Federal Reserve stock is now probably a nentral factor in the costs and benefits of menbership. Therefore, Federal Reserve Bank stock is not inchnded in the following discussion of the reserve burclen of ne'tuber banks or the exsts of nembership.

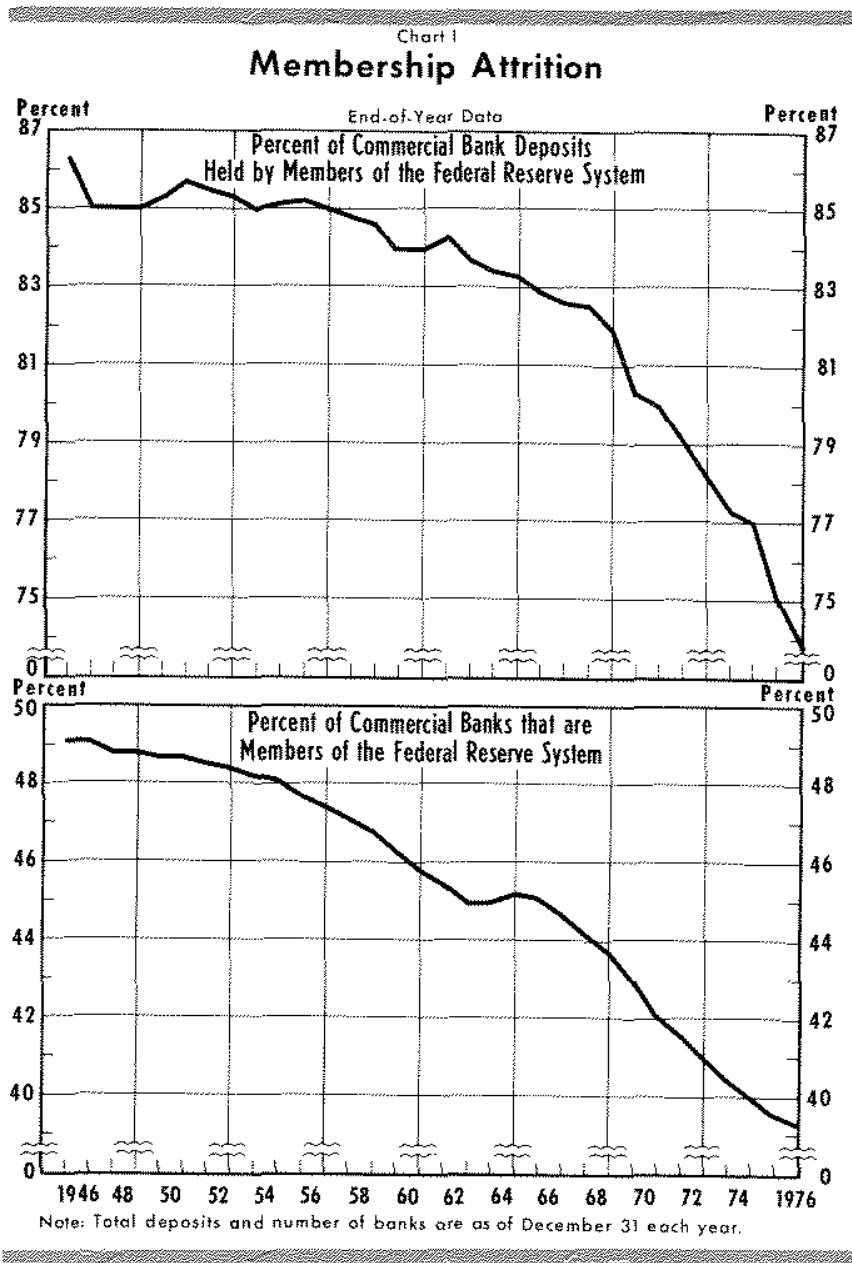

deposit liabilities, whereas reserve requirements for member banks are graduated so that requirements are lower for smaller banks. The significant difference between the reserve requirements of member and nonmember banks concerns the types of assets they can use to meet their legal reserve requirements.

In most states nonmember banks can meet their reserve requirements with vault cash, cash items in the process of collection (CIPC), and demand balances due from other commercial banks. Member banks can meet their reserve reguirements only with 
vault cash and collected reserve balances at the Federal Reserve Banks.

The reserve burdens of most nonmember banks are reduced substantially because they are permitted to use CIPC to meet state requirements. Their CIPC represent primarily the value of checks they have deposited with correspondent banks for which the correspondents have not yet received payment. ${ }^{3}$ On the other hand, when member banks deposit checks with Reserve Banks, they receive credit to their reserve accounts according to a schedule which depends upon the location of the banks on which the checks are drawn. Member banks receive immediate credit for some checks, but for others credit is delayed one or two days. The deferred credit schedule approximates the time required for the Federal Reserve System to receive payment for outstanding checks.

To demonstrate the significance of CIPC for the relative reserve burdens of member and nonmember banks, the ratios of CIPC to reserve balances were calculated for a group of 49 member banks that are served by the St. Lotis office of the Eighth. Federal Reserve District and which regularly clear both local and out-of-region checks through this Reserve Bank. The four largest correspondent banks in the area were excluded from these calculations since their CIPC are exceptionally large in relation to their reserve balances. Average daily reserve balances of those member banks would have been 82.6 percent greater if they could have counted CIPC as part of their reserves.* Another indication of the significance of CIPC is Knight's estimate that, on average, only 56 percent of demand balances that banks hold at correspondent banks are collected balances. ${ }^{5}$

Another significant difference between reserve requirements of states and those of the Federal Reserve is that nonmember banks can meet state reserve requirements with deposits at correspondents. As indicated below, correspondents offer respondent banks higher implicit rates of retum on demand balances in the form of services than the implicit returns member

\footnotetext{
3 Nonmember banks are officially allowed to count their CIPC as reserves in less than half of the states. However, in the other states nonmembers can count CIPC as reserves by recording all deposits of checks with their correspondents as demand balances due from correspondents, whether the funds are available for their use immediately or with some delay due to the time required for collection.

*Average daily reserve balances and CIPC were calculated for the period September 9, 1976, through January 12, 1977.

thobert E. Knight, "Comparative Burdens of Federal Reserve Member and Nonmember Banks," Monthly Review, Federal Reserve Bank of Kansas City (March 1977), pp. 24-25.
}

banks receive on their reserve balances at Reserve Banks. In addition, in about half of the states, nonmember banks can meet various proportions of their reserve requirements by holding interest eaming government securities, and the Federal Reserve enforces its reserve requirements more rigorously than do most states. ${ }^{6}$

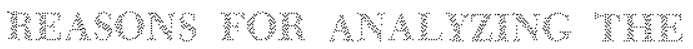

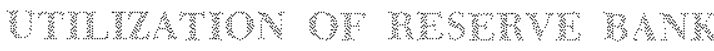

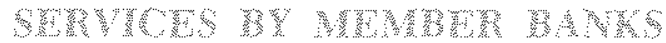

Empirical studies support the view that member banks have greater reserve burdens than nonmembers by showing that member banks have higher cash/asset ratios than nonmember banks of the same size, especially among smaller banks. ${ }^{7}$ However, these studies do not show in general that the reserves of member banks at Reserve Banks are larger than the demand balances that nommember banks hold at correspondents. The cash/asset ratios of nember banks are higher than those of nonmembers because many member banks hold their required reserves at the Federal Reserve and hold substantial demand balances at correspondent banks.

Therefore, analysis of the cost of Federal Reserve membership involves more than just comparison of reserve requirements of the Federal Reserve with those of the states. It also involves examination of reasons why member banks hold large balances with correspondents. One of the maior reasons banks hold demand balances at correspondent banks is to compensate correspondents for their use of services. Thus it is relevant to examine the services that mem-

iI 30 states there are no specifed dollar penalties for reserve deficiencies for nonmember bauks.

${ }^{7}$ Cash assets of banks are generally measured as their vault casli, demand balances dne from correspondents, cash items in the process of collection, and reserve balances at Reserve Banks. See Gary G. Gilbert and Manferd $O$. Peterson, "Reserve Requirements, Federal Reserve Membership and Bank Perfonmanoe," FDIC Woking Paper No. 74-8, and "The Impact of Changes in Federal Reserve Membership on Commercial Bank Performance," Joumal of Finance (June 1975), pp. 713-19; Robert E. Knight, "Reserve Requirements Part 1: Comparative Reserve Requirements of Member and Nommember Banks," Monthly Review, Federal Reserve Bank of Kansas City (April 1974), pp. 3-20; Robert J. Lawrence and Duane Lougee, "Determinants of Correspondent Banking Relationships," Jonrnal of Moneu, Credit and Banking (August 1970), pp. 358-69; Lncille Mayne, The Effect of Federal Reserve System Membership on the Profitability of Illinois Banks, 1961-63 (Center for Research of the College of Business Administration, Pennsylvania State University, 1967); Walter A. Varvel, "The Cost of Membership in the Federal Reserve System," Federal Reserve Bank of Richmond, Working Paper 77-1, March 1977. 


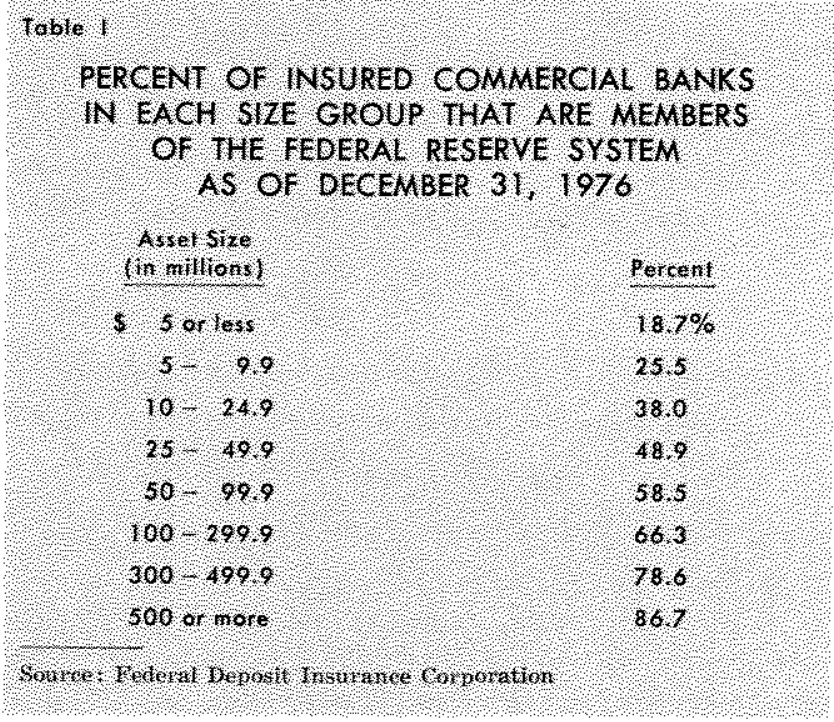

ber banks obtain from Reserve Banks and services that they receive from correspondents.

Another reason for examining the use of Reserve Bank services by member banks concerns the size distribution of member banks. In most states reserve requirements for nonmember banks are either flat percentages of various types of deposit liabilities or less graduated than requirements of the Federal Reserve. Also, the ratio of CIPC to total deposits tends to be positively related to bank size. If relative re- serve requirements were the only basis on which banks decided whether to be members of the Federal Reserve, these two reasons would cause the largest banks to have the greatest incentives to drop membership. Yet this is not the case.

Table I indicates that the percentage of banks that are Federal Reserve members increases with the size of banks. Table II shows that the size distribution of banks withdrawing from membership during 1971 through early 1977 corresponds closely to the size distribution of all members at the end of last year, but that no banks with total deposits over $\$ 1$ billion withdrew from membership during that period. So there must be additional factors which infuence the decisions of banks concerning Federal Reserve membership. One such factor is the utilization of Reserve Bank services by member banks.

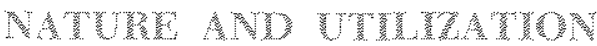

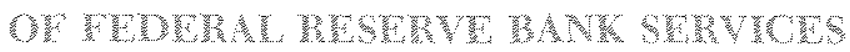

Services that Reserve Banks provide to member banks are discussed in approximately the order of cost to the Federal Reserve System of providing them, as indicated in Table III. Information on the utiliza. tion of services by member banks of differing size is derived from a survey which includes 233 member

$1 \mathrm{sul}$

SIZE DISTRIBUTIONS OF NSURED BANKS IN THE US, THAT WITHDREW FROM FEDERAL RESERVE MEMBERSHIP, JANUARY 1971 MARCH 1977 , AND ALL MEMBER BANKS, DECEMBER 31,1976

\begin{tabular}{|c|c|c|c|c|c|}
\hline 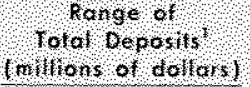 & Nunber & Eercentoge & Cnmalle & percenlose & Cunulatue \\
\hline 10105 & 15 & $50 \%$ & $50 \%$ & $66 \%$ & 6,6 \\
\hline 51010 & 42 & 141 & 19 & 14 & 201 \\
\hline 101020 & 1 & 258 & 44 & 248 & 455 \\
\hline 201030 & 46 & 154 & 603 & 159 & 014 \\
\hline 30104 & 30 & 10, & 704 & 88 & 70,3 \\
\hline 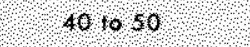 & 1 & 57 & 70 & 56 & 769 \\
\hline 501060 & 14 & 47 & 808 & 36 & 95 \\
\hline 601075 & 1 & 24 & 832 & 43 & 840 \\
\hline ? & 12 & 10 & 872 & 36 & 878 \\
\hline 10010150 & 18 & 34 & 926 & 40 & 916 \\
\hline 13010250 & 1 & 24 & 950 & 28 & 944 \\
\hline 25010500 & 12 & 40 & 90 & 27 & 97 \\
\hline 400101,000 & 3 & 10 & 1000 & 14 & 98, \\
\hline $1,000 \mathrm{snd} 0 \mathrm{ret}$ & 0 & 00 & 1000 & 15 & 1000 \\
\hline ४ Tol & 298 & 10000 & & $1000 \%$ & \\
\hline
\end{tabular}

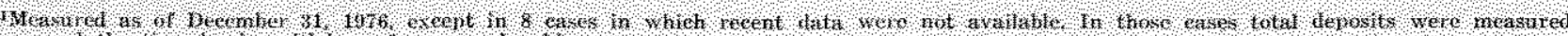

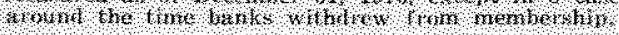




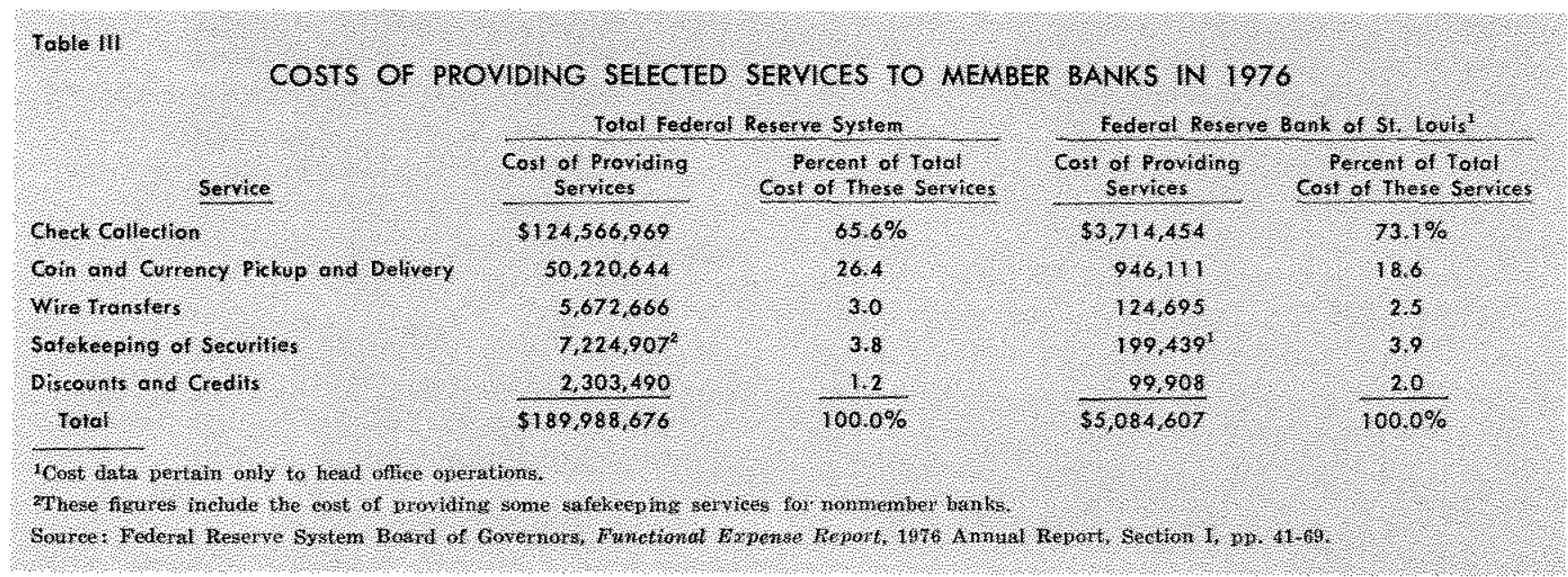

banks served by the head office of this Bank. Banks are ranked by total assets and divided into groups of 20 each, except for group 12, which includes the 13 largest banks in the survey. Results, summarized for each group, are presented in Table IV.

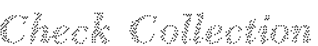

The service to member banks that is the most expensive for Reserve Banks to provide to members is collection of checks. The Federal Reserve System provides the only national system of check collection, through which 13.2 billion checks were cleared in 1976. This represents about 45 percent of all checks written in the nation last year.

Member banks may deposit for credit to their reserve accounts checks drawn on any other domestic bank that remits at par. ${ }^{8}$ There is no direct charge to member banks for this service. Since the early $1970 \mathrm{~s}$, nonmember banks located in zones served by Regional Check Processing Centers have been permitted to deposit at Reserve Banks checks drawn mpon other banks in their regions. Deposits of such checks are credited to the reserve accounts of member banks that serve as correspondents. There is no charge to nonmember banks for this service. Nommember banks collect out-of-region checks through their correspondents. All checks deposited with Reserve Banks must be encoded with bank routing numbers and dollar amounts. Banks depositing more than a certain minimum number of checks must sort checks by location of the banks on which the checks are drawn.

8A non-par bank charges a fee when checks drawn upon accounts of its depasitors are presented for collection by any means other than at the bank's own teller window. Reserve Banks will not accept checks drawn upon such banks for deposit to a member bank reserve account. As of December 31,1975 , there were only 73 non-par banks in the nation.
A survey of checks deposited with this Bank was conducted in January of this year. Column (4) of Table IV reports the percentages of banks within each size group that deposited more than five checks during that month." A large majority of banks with total assets under $\$ 100$ million clear checks through correspondents.

For each bank that deposited more than five checks with the Reserve Bank, the number of checks deposited in January was multiplied by 12 to get an annual rate, and averages within each size group are reported in column (5).10 A few large banks deposited most of the checks. For instance, the 12 largest banks deposited 79 percent of all checks, and the five largest deposited 74 percent. These figures actually understate the share of checks directly deposited by the largest banks since several of these large banks send checks drawn on banks in other Federal Reserve districts directly to the other Federal Reserve Banks. The survey does not include information on the number of such checks.

Another function involved in check clearing is that of banks paying their Reserve Bank for checks drawn upon them (remitting for the Fed's cash letters). The percentages of banks in each group that remit by having their reserve accounts debited are indicated in

There were 15 member banks that deposited from one to five checks in January. To include those banks in the percentages in column (4) would exaggerate the number of banks using the Reserve Bank's check clearing facilities.

10The volume of checks deposited with Reserve Banks in the first quarter of each year tends to be about three percent below the volume for the previous fourth quarter. Therefore, these figures probably understate the annual rate at which banks deposit checks. Since the Board of Governors of the Federal Reserve System reports volume of checks data only on a quarterly basis, there is no accurate means of adfusting one month's data for seasonal influences. 
column (6). Those member banks not using this method arrange for the reserve accounts of their correspondents to be debited, the same method of settle ment that is used by nonmember banks.

This settlement function is analyzed as a separate service since the method that member banks use for settlement involves costs and benefits which are different from the costs and benefits involved in the method used for clearing checks. If member banks choose to settle through their reserve accounts, they incur transactions costs involved in meeting their weekly requined reserves. If they settle through cor respondents, they must compensate correspondents for record keeping and for the transactions costs which they create for their correspondents.

In most size groups in Table IV, the number of banks that have their reserve accounts debited for checks drawn upon them is greater than the number that deposit checks directly with the Reserve Bank. This is probably because depositing checks directly with the Reserve Bank involves more processing by member banks (encoding and sorting) than correspondents require. Remitting for the Fed's cash letters through the reserve account involves only somewhat more frequent adjustments to a member bank's reserve account than remitting through a correspondent's account. However, most of the smaller member banks use a conrespondent's account to settle for checks drawn upon themselves. For instance, of the 100 smallest members in the survey, only 16 settle through their reserve accounts, and of the next 100 largest, 38 settle through their reserve accounts.

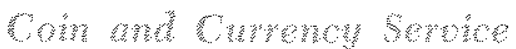

One of the important operational functions of Reserve Banks is removing defective currency from circulation and issuing new currency. Reserve Banks provide both member and nonmember banks with coin and currency. Amored car service for pick np and delvery of coin and curency is mate avalable daily at offices of member and nommember banks in metropolitan areas surrounding offices of Reserve Banks and weekly in other areas. Banks not located on armored car routes receive coin and currency from Reserve Banks through the mail. This service is provided to member banks without charge, whereas nonmember banks are charged fees to cover costs. Reserve Banks change both members and nonmembers a fee for wrapped coin to cover the cost of that operation.
Information on the coin and currency service used by member banks is presented in columns ( 7$)-(10)$ of Table IV. Column (7) indicates that most member banks receive armored car service. Almost all of the others receive Federal Reserve coin and currency service through the mail (see columm 8). The remain ing member banks receive money service from correspondents.

When member banks receive money shipments or deposit coin and currency at the Reserve Bank, they can have the Reserve Bank debit or credit their re serve accounts or those of their correspondent banks. Such practices vary among member banks, as indicated in column (9). The method of debiting and crediting for a bank's money service, either through its reserve account or a correspondent account, can be considered a separate aspect of this service, as in the discussion above about settlement for checks drawn upon a member bank.

The degree to which member banks of various sizes use the Federal Reserve's coin and currency service is quantified in column (10) in terms of fees that member banks using this service would be charged as nonmembers. The annual value of coin and currency service to each nember bank was calculated at fees charged nonmember banks based upon utilization of that service in September, October, and November of last year. For banks in each size group that receive money service from the Reserve Bank, the average amual value of their money service is presented in coltemn $(10) .11$

\section{Whe rangers}

A Reserve Bank service that is offered exclusively to member banks at no charge is wire transfers transferring funds electronically from the reserve account of one member bank to the reserve account of any other member bank in the country. ${ }^{12}$ This system is used heavily for conducting transactions in the Federal funds market and for making payments for large business customers. Many of the large member banks use the wire transfer service through on-line equipment, initiating and receiving notice of transac-

\footnotetext{
17There were not sufficient data to calculate the fees member banks receiving coin and currency service through the mail would have been charged for such nail service as nonmenbers. The vatue of the "maled money" service for members was calculated based upon what they would have paid as a nomenber for the same value of coin and currency shipments provided turongh armored car service.
}

12There is a charge fot transfers of less than $\$ 1,000$. 


\begin{tabular}{|c|c|c|c|c|}
\hline \multirow[b]{2}{*}{$\begin{array}{l}\text { Group } \\
\text { Number }\end{array}$} & \multicolumn{4}{|c|}{ 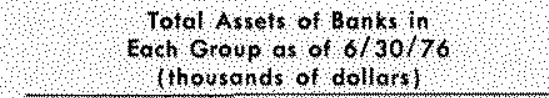 } \\
\hline & & Average & Maximum & $\begin{array}{l}31 \\
\text { Minumum }\end{array}$ \\
\hline 1 & 5 & $3,891,6$ & 6,312 & \\
\hline 2 & & $7,79.8$ & 8268 & 6,38 \\
\hline 3 & & $9,592,3$ & 10,351 & 8,270 \\
\hline 4 & & $11,706,4$ & 12998 & 10.533 \\
\hline 5 & & $15,051,6$ & 16,395 & 13,0 \\
\hline 6 & & $17,723.6$ & 19.995 & $16 . \mathrm{A}$ \\
\hline 7 & & $21,790.2$ & 23,766 & 20,3 \\
\hline 8 & & 25,9912 & 27536 & 24,158 \\
\hline 9 & & 309520 & 34,037 & 27,580 \\
\hline 10 & & 40,961 & 46,755 & 34,52 \\
\hline 11 & & 691068 & 107,641 & 46,83 \\
\hline 12 & & $125,173,8$ & $1,743,592$ & 107,932 \\
\hline
\end{tabular}

(10)

(1)

(12)

Averoge Annuol
Number of
Checks Cleored
by Bonks hot
Cleor Checks
Through he
Reserve Bonk

percentol for the fed Cash letters.

Through Debits to Their Percent of hrough armore cor or Mal. Bants that through the Reserve Theor Chat Reserve Bank

$5 \%$
0
25
10
30
10
40
30
30
9
2

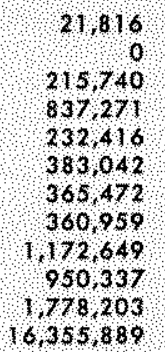

114 Reserve Accomnts Money Serrice percent Hoving Service Deblied and

$15 \%$
0
20
20
20
35
20
50
50
35
75
92

\section{$75 \%$} Mall Creditad

\begin{tabular}{|c|c|}
\hline $20 \%$ & \\
\hline 50 & 58 \\
\hline 40 & 74 \\
\hline 30 & 58 \\
\hline 20 & 47 \\
\hline 25 & 60 \\
\hline 15 & 80 \\
\hline 10 & 75 \\
\hline$\$$ & 65 \\
\hline 4 & 70 \\
\hline 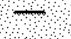 & To \\
\hline & \\
\hline
\end{tabular}

171

181

Peront of Bonk Holding US Governmen

Of Bank wolding Securities in Book Entr, Averogs 14 Or Bonks Holding Inifioting Wire Implicit subsidy to Nember Percent of Banks Inithating transfers securities in Boo Anount Group 1 Bonks from Wire Transfers Frequently.

Eneserve ol one Whousonds of
dollarsi Ho Securtites of tho

Reseno sonk at the Reserve?

Percent of Banks that to 7 thet? bonk, Average were Regular Sertices Used by Member Bonks os Percent of Theit. Inestnent scoount

Amount 150 (1) thousands of 1, Window,

$\$ 664,42$

83871

830.95

181350

046,53
230,80

$2,230,80$
170080

$2,036.80$

$2,036.80$
$2,087.80$

$2,087,80$

$3,376.00$

12,90077

$15 \%$
10
5
30
20
50
35
65
65
70
75
85

\begin{tabular}{|c|c|}
\hline $30 \%$ & 427.0 \\
\hline $70 \%$ & 98.53 \\
\hline 50 & $1,082,5$ \\
\hline 40 & 0,6316 \\
\hline 58 & 1,2167 \\
\hline 70 & 10514 \\
\hline 55 & 1,4751 \\
\hline 80 & $2,03 \%$ \\
\hline 75 & $2,466.1$ \\
\hline 75 & $1,254,0$ \\
\hline 70 & 5,9450 \\
\hline 100 & 123,8088 \\
\hline
\end{tabular}

$\$, 49$,

68
102
102
134
92
95
94
191
312
176
704
19649

$25 \%$
35
35
30
45
50
35
70
65
80
65
69

$9751976^{5}$

Averoge Daily

Reserte Boloness:

$0,594 \%$
0,294
0,349
0,344
0.275
0,752
0313
0,481
0,880
0,589
015
603

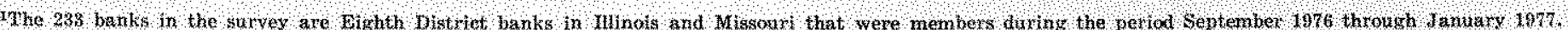

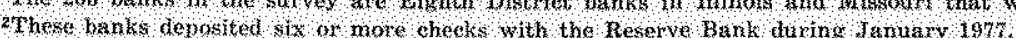

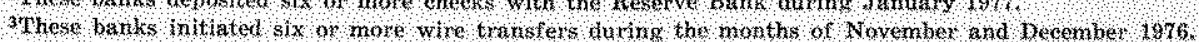

These are wat values of securitie helt th safekeeping as of November 30 , 1976

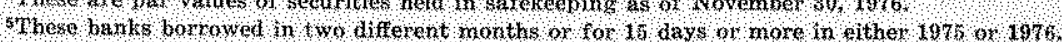

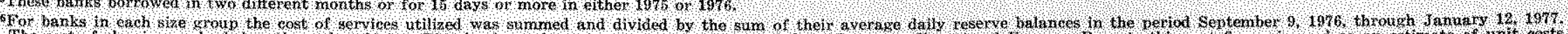

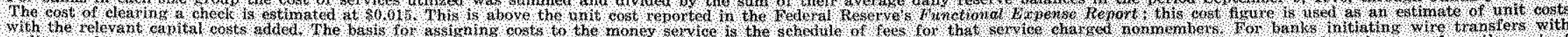

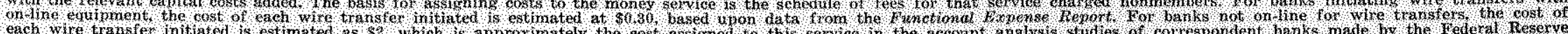


tions through their own terminals. Other member banks initiate wire transfers by telephone, giving employees at Reserve Banks details of transactions. Nonmember banks may use this funds transfer system only indirectly through member banks. During 1976 , member banks initiated 21 million wire transfers with a total dollar value of $\$ 35,617.8$ billion.

Based upon a survey in November and December of last year, many of the banks either initiated no wire transfers or made minimal use of the service. ${ }^{13}$ Frequent users of the wire transfer service are defined as those initiating more than five wire transfers during the two month period; column (11) presents the percentage of banks in each size group that initiated wire transfers frequently.

The number of wire transfers originated by frequent users was multiplied by six to get annual rates; averages of those annual rates for frequent users of the service are presented in column (12). These calculations indicate that banks in the largest size group initiated most of the wire transfers. As additional evidence, the four banks that initiated the most wire transfers accounted for 86.8 percent of wire transfers that were sent by all banks in the survey, including those of the infrequent users.

\section{Sulekephing of socumes}

Reserve Banks hold securities in safekeeping for member banks at no cost to members. Securities are held in two forms:

(1) Certain Federal Government obligations are held at Reserve Banks in book-entry form. No physical debt certificates are issued by the Treasury, but ownership records are kept on the books of the Reserve Banks. Customers of member banks may also hold Federal debt obligations in this form, with the member banks acting as their agents for this service. Ownesship of these securities may be changed through wire transfers.

(2) The other form in which securities are held in safekeeping at Reserve Banks is that of definitive securities - acteral paper evidence of debt obligations (not limited to Federal Government debt). Reserve Banks collect bond coupons for member banks at no charge, and collect matured bonds at no charge other than shipping charges for collection outside Federal Reserve Bank cities. Collected funds are credited to the reserve accounts of member banks.

13 Of the 233 banks in the survey, 78 initiated no wire transfers ditring that period. All but three of the banks not ising that service had total assets less than $\$ 35$ million. The banks initiating from one to fve wire transfers ( 57 in total) are atso relatively small; all but nine had total assets less than $\$ 35$ million.
Reserve Banks hold, for nonmembers, Federal Govermment securities that are required as collateral for U.S. Government deposits at those banks. Reserve Banks also accept, from nonmembers, custody of securities that are pledged as collateral to deposits of bankrupt estates. Other than in these two cases, nonmembers are not allowed to keep securities for their own investment account or for the accounts of their customers in safekeeping with Reserve Banks.

Columns (13) - (16) of Table IV present information on securities that member banks hold in safekeeping with the Reserve Bank. Some member banks do not use this service, preferring to hold securities with their correspondents or in their own vaults. Use of the safekeeping service of the Reserve Bank is somewhat related to bank size, with a greater percentage of the larger banks using this service. However, more of the smaller banks use this service than they do the Reserve Bank's check clearing or wire transfer services.

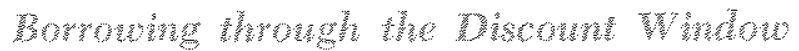

Reserve Banks make loans to member banks for various purposes and durations. In the most common situation, a member bank borrows for only a few days at a time, presumably to adjust its reserve position to unanticipated deposit withdrawals or loan demands. This type of lending is called adjustment credit. Certain member banks with distinct seasonal patterns in loan demand and deposit flows qualify for seasonal borrowing privileges, under which they may borrow fixed amounts from Reserve Banks for several consecutive months. A third category of Federal Reserve lending is emergency credit, involving loans for extended periods of time to member banks experiencing financial difficulties that make other sources of funds unavailable to them at prevailing market interest rates. Emergency credit is made available at a higher discount rate than the rates for adjustment credit or seasonal lending. In some circumstances emergency credit can be made available to nonmember banks, but at a higher interest rate than emergency credit for member banks.

The discount rate was above the Federal funds rate during most of 1975 and 1976. Therefore, banks that borrowed the discount window during those years were generally borrowing to make short-term adjust ments to their reserve positions rather than borrowing to profit from a relatively low discount rate, as many banks did in 1974. Banks that are "regular" borrowers at the discount window are identified in this paper as 
those that borrowed in either two different months or for a total of 15 days or more in either of the past two years. These "regular" borrowers are assumed to be relying upon the discount window as an important source of short-term credit.

Only 21 banks are identified as "regular" borrowers (see column (17), Table IV). ${ }^{1+}$ Note that 15 of them had total assets of less than $\$ 35$ million. Thus, although most member banks do not borrow when the discount rate is above money market rates, the discount window is an important source of short-term credit for several of the smaller member banks.

\section{Aggregathe he Benefts of Membership}

The benefits of Federal Reserve membership are measured by summing the costs to the Federal Reserve of providing services to member banks and dividing by their respective average reserve balances at the Reserve Bank. This percentage is called an implicit rate of return on reserve balances. Average implicit returns are presented in column (18) of Table IV. The numerator of this ratio is an estimate of the cost to the Reserve Bank of providing check clearing, money service, and wire transfers. This approach overstates the benefits of membership from these services to the extent that member banks use more of these services at zero explicit prices than they would as nonmembers, paying for services by explicit fees or correspondent balances.

Means of allocating the costs of services to individual member banks are discussed in Table IV. No suitable basis was devised for allocating the costs of safekeeping of securities and credit discount services to individual member banks, but, as indicated in Table III, the three services included in calculations in column (18) - check clearing, coin and currency service, and wire transfers - account for about 95 percent of the costs of services provided. Therefore, allocating just the costs of these three services to member banks provides suitable estimates of the benefits of membership measured in terms of costs of services used.

In all size groups the implicit rates of return on reserve balances are quite low. ${ }^{15}$ The highest per-

1:Only 24 menber banks out of 233 in the survey borrowed at any time during 1975 76 . Therefore, most of the banks that borrowed are identified as regular borrowers.

15These rates of return would be even lower if the costs of services provided to members were strictly limited to those oflered exchisively to nember banks. A large shate of the onsts of services provided to members in these calculations centages are for the largest group of banks in the survey, averaging 1.69 percent. The calculated implicit returns for the largest banks are understated since they do not include the costs to the Federal Reserve System of clearing checks that several of those banks sent directly to other Reserve Banks. For the smaller member banks (the 200 smallest in the survey), the implicit retums average about one-half of one percent.

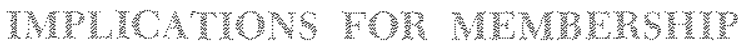

Data on implicit returns to the smaller nember banks relative to their reserve balances indicate why smaller banks have incentives to withdraw from membership. The survey has too few observations on the utilization of Reserve Bank services by large banks to offer an explanation for why most large banks have remained in the Federal Reserve System.

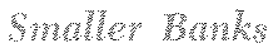

Division of banks into categories of large and small is somewhat arbitrary. For purposes of this discussion small banks are identified as those with total assets less than $\$ 50$ million (or roughly those in groups 1-10 in Table IV).

Table IV indicates that most of these banks use few Reserve Bank services. The implicit rate of return on reserves averaged about one-half of one percent for those banks. These results indicate that for most of the smaller member banks, Federal Reserve services are more expensive than the services of correspondent banks, which are close substitutes for the services offered by Reserve Banks.

Implicit returns on demand balances at correspondent banks, similar to the implicit returns on reserve balances discussed above, can be derived from studies of account analysis at correspondent banks. The correspondent banks that perform account analysis keep records of services used by respondent banks and assign dollar values to the utilization of services based upon the costs to the correspondent banks of providing those services. Correspondent banks multiply the average collected demand balances of respondent banks by implicit interest rates, called earnings allowances, to determine periodically whether respondent banks have been holding large enough demand balances to compensate for the services they use.

is the cost of clearing checks drawn upom banks located within the region served by their own Regional Check Processing Center. Nonmember banks may also present such checks to Reserve Banks for collection. 
In a survey of 130 correspondent banks conducted by Knight in July 1976, the earnings allowances on collected demand balances, unadiusted for the required reserves of correspondent banks against those deposits, ranged from 3.34 to 6.19 percent with an average of 4.5 percent. ${ }^{16}$ These percentages indicate the implicit returns respondent banks may receive on their collected demand balances at correspondents if they fully utilize the services made available to them. Thus, correspondent banks make available signifcantly more services per dollar of collected demand balances than do Reserve Banks, assuming that Reserve Banks are not substantially more efficient than correspondent banks. ${ }^{17}$

This conclusion could be challenged on the basis that the smaller member banks could increase their implicit returns on reserve balances substantially if they just made fuller use of Reserve Bank services. This issue is investigated by calculating the implicit returns on reserve balances for a group of banks

16For a deseription of the methodology used in that study of account analysis, see Robert E. Knight, "Account Analysis in Correspondent Banking," Monthly Review, Federal Reserve Bank of Kansas City (March 1976), pp. 11-20. The earnings allowances reported it the survey of July 1976 were for collected demand balances of respondent banks net of required reserves that correspondent banks must hold against those deposits. In the discussion above, those earnings allowances were converted to a basis of collected balances unadjusted for requiled reserves by multiplying by one minus the marginal reserve requirement on demand deposits for correspondent banks, which is assumed to be 16.5 percent, the marginal reserve requirement for member banks with demand deposits greater than $\$ 400$ million. This adjustment is made to the eamings allowances by correspondent banks to make them more comparable to the implicit returns on reserve balances of member banks calculated above.

${ }_{17}$ Comparisons of implicit returns that member banks receive on their reserve balances to the earning allowances at correspondent banks understate to some extent the differences in implicit yields on reserve balances and collected demand balances at correspondent banks. This bias results from the fact that correspondents are not charged fees for the Reserve Bank services they use as part of their service to respondent banks, and therefore, do not have to include the costs to the Reserve Banks in offering those services in their implicit charges to respondent banks in order to price their services profitably. An objection might be raised to this conclusion on the basis that correspondent banks must set their implicit charges on services they offer to respondent banks high enough to cover their costs of Fefleral Reserve membership in terms of foregone earnings on the large reserve balances they must hold. If this objection is valid, it would mean that comparison of implicit returns on reserve balances to earmings allowances at correspondent banks would overstate the differences in yield on reserve balances in terms of services relative to the implicit yields on demand balances at correspondents. However, this objection is not valid since the eamings allowances reported above equal the eamings allowances from the recent study of accounts analysis at correspondent banks multiplied by one minus the marginal reserve requirement on demand deposits, thus removing this second source of potential bias. with total assets less than $\$ 50$ million which make relatively full use of Reserve Bank services. Each of the banks included in this analysis regularly clears local and out-of-district checks directly through the Reserve Bank. There are 34 such banks served by the head office of this Bank. Their total assets as of June 1976 ranged from $\$ 8.8$ to $\$ 49.9$ million, with average assets of $\$ 27.6$ million. ${ }^{18}$ All of these banks receive coin and currency service from the Reserve Bank, and all but three of them initiated wire transfers.

The average implicit return to these banks on their reserve balances is 1.32 percent. Thus, although member banks which utilize Reserve Bank services more fully than average can increase their implicit returns on reserve balances substantially, their implicit returns still will be low relative to the implicit interest rates on collected demand balances at correspondents.

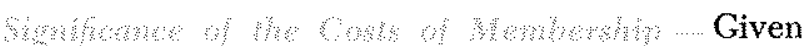
the relatively low implicit returns to member banks on their reserve balances, a remaining question is the size of the costs of Federal Reserve membership in relation to bank profits and capital. If the costs of membership are positive but insignificant, current members would not have strong incentives to withdraw from membership. The costs of membership are estimated for a group of member banks which make minimal use of Reserve Bank services. The characteristics of those banks and the procedure for calculating their costs of Federal Reserve membership are presented in the Appendix. Membership costs of banks making minimal use of Reserve Bank services are analyzed because measuring the costs to those banks of obtaining services as nonmembers requires few assumptions.

For the 54 banks included in the analysis, the costs of Federal Reserve membership averaged 1.8 percent of their equity capital in 1976. The cost of membership as a percent of 1976 profits before income taxes and securities gains and losses averaged 11.2 percent among 49 banks with positive profits last year. These calculations indicate that for the smaller member banks making little use of Reserve Bank services, there is a substantial cost associated with Federal Reserve membership.

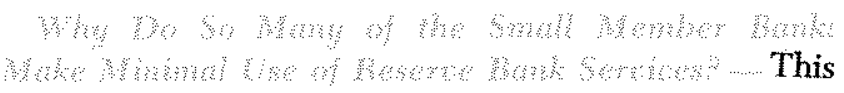

${ }^{18}$ Two other banks had these characteristics but were excladed from this analysis because their utilization of services was unusually great. Apparently those banks serve as check processing centers for other banks in their holding companies. 
analysis has not explained why most of the smaller member banks make little use of Reserve Bank services. Explanations could be offered for each service separately. For instance, one explanation for why most of the small member banks clear checks through correspondents is the Fed's encoding and sorting rem quirements. However, a more general explanation, which is supported by the evidence in the sections above, is that most of the smaller member banks find the transactions costs of managing their reserve acconnts, while using Reserve Bank services, greater than the benefits derived from using those services.

Use of Reserve Bank check clearing services involves frequent debits and credits to a member bank's reserve account. Having a reserve account debited and credited for money shipments also creates some problems for a member bank in managing its resrve position. When a member bank orders a currency shipment, its reserve account is debited, but the funds transferred to the bank as vault cash are not counted as part of reserve assets for two weeks. For the current reserve settlement week, the funds withdrawn from the bank's reserve account must in general be replaced with funds from another source in order to meet reserve requirements. Use of other Reserve Bank services - wire transfers, safekeeping of securities, and borrowing through the discount window - involves similar adjustments to the reserve positions of member banks.

Member banks know the average reserve balances they are required to hold during each reserve settlement week at the beginning of the week, and most member banks receive statements daily on the balm ances in their reserve accounts. Even though the Reserve Banks provide members with this information, member banks incur transactions costs in managing their reserve positions if they are using Reserve Bank services which involve frequent debits and credits to their reserve accounts. Banks tising such services must monitor their reserve positions closely, ptoject debits and credits to their reserve accounts, sell assets or borrow funds to avoid reserve deficiencies when there are unanticipated debits, and buy assets or lend funds to avoid large excess reserves when they have unanticipated credits.

Large banks cope with such reserve management problems by employing specialists in that function. According to the explanation for the behavior of the smaller nember banks developed in this section, a large proportion of them prefer not to incur the transactions costs that result from using Reserve Bank services directly. Instead they prefer to hold relatively idle balances at the Reserve Bank to meet reserve requirements, obtaining services through correspondents and using their demand balances at correspondents as their working balances. As explained above in the discussion of account analysis at correspondent banks, correspondents require respondent banks to hold average demand balances in some proportion to the costs of services they use. However, correspondent banks require this balancing out less frequently than once it week, thus allowing their respondent banks more flexibility in the use of their demand balances than Reserve Banks allow members in the use of their reserve balances.

Data from the survey discussed above include several observations which tend to support the hypothesis that many of the smaller nember banks avoid using Reserve Bank services because of the reserve management problems that would result. Note in columns (6) and (9) of Table IV that in most size groups more banks have their reserve accounts debited and credited for money shipments than have their reserve accounts debited for checks drawn upon them. A member bank orders money shipments in advance and therefore can plan its reserve management over a reserve settlement week, taking such entries into consideration. In contrast, debits to a member bank's reserve acconnt in remitting for the Fed's cash letters come in amounts and with timing that camnot be foreseen accurately. Therefore, one explanation for why more member banks order money shipments through their reserve accounts than settle for checks drawn upon them through their reserve accounts is that debits and credits due to money shipments create smaller transactions costs in managing their reserve positions.

Another observation that supports this view is that the smaller banks which do use services involving frequent debits or credits to their reserve accounts tend to use other such services. Use of one such service forces a bank to deal with the problem of managing its reserve account subject to frequent debits or credits. Thus, using other such Reserve Bank services imposes a smaller marginal burden.

There are 58 banks among the 200 smallest in the recent survey that either deposit checks directly with the Reserve Bank or pay for checks drawn upon them through their reserve accounts. Use of these services involves the most frequent and umpredictable debits and credits to reserve accounts. Of these banks, 52, or 89.7 percent, have their reserve accounts debited and credited for money shipments; of the other 142 mem- 
ber banks among the 200 smallest in the survey, only 69 , or 48.6 percent, have their reserve accounts debited and credited for money shipments.

A similar difference in behavior exists among these banks with respect to use of the wire transfer service. Of the same 58 banks, 39 , or 67.2 percent, initiated more than five wire transfers during a twomonth period, whereas among the remaining 142 banks, only 33 banks, or 23.2 percent, initiated wire transfers that frequently. Many of the member banks that did not initiate wire transfers through the Reserve Bank probably did so through correspondents.

The discussion above indicates a preference among the smaller member banks for holding relatively idle balances at Reserve Banks to meet their reserve requirements and holding more active demand balances at correspondents which serve as their working balances. Results in Table $V$, using observations for all Eighth District member banks, reflect such a pattern of behavior.

One measure of activity in reserve balances and demand balances at correspondents is the standard deviation of daily balances divided by the mean of daily balances. For banks in each size group excluding the 25 largest banks, their demand balances at correspondents are, on average, more variable than their reserve balances, indicating that the smaller member banks tend to hold relatively idle balances with the Reserve Bank and use their demand balances at correspondents as their working balances.

Another measure of variability in daily balances presented in Table $\mathrm{V}$ is the average number of days that balances in an accomt did not change from the previous day. To indicate the limits on these numbers, the data used cover 126 days, and the minimum number of days a bank's reserve balance could remain unchanged is 36 , due to weekends and holidays. Many of the smaller member banks leave their reserve bal ances unchanged for several days in a row. The number of days reserve balances remained unchanged averaged 76.5 among the 60 smallest banks and tended to decline as bank size increased. The number of days demand balances at correspondents remained unchanged were approximately the mininum for banks in all size groups.

Member banks that use the services of correspondents, instead of the services provided by their Reserve Banks, must hold stbstantial demand balances at correspondents to compensate for the services they use. Thus, many member banks bear double reserve burdens, meeting the reserve requirements of the Federal Reserve and holding demand balances at correspondents that are large enough to exceed the reserve balances that would be required of them as nonmember banks.

In most states nonmember banks can meet their reserve requirements with demand balances at correspondents and CIPC. The last column of Table $\mathrm{V}$ indicates that in all size groups Eighth District member banks hold average daily demand balances at correspondents plus CIPC that are larger than their average daily reserve balances at the Reserve Bank. The ratio of demand balances at correspondents plus CIPC to reserve balances is especially high among the smallest member banks and the largest member banks in Table $V$, the large correspondent banks having especially large CIPC. ${ }^{19}$

These observations do not necessarily imply that most member banks would hold the same level of demand balances at correspondents if they became nonmembers. Several studies show that nonmember banks hold larger demand balances at correspondents than member banks of the same deposit size. ${ }^{20}$ The observations in the last column of Table $\mathrm{V}$ do indicate that most member banks hold assets that would count as reserves if they were nonmember banks which are larger than their current reserve balances at the Reserve Bank.

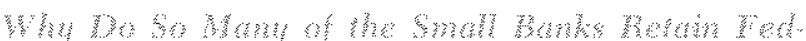

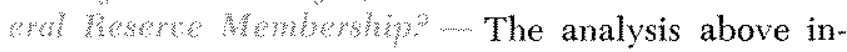
dicates that there are substantial costs associated with Federal Reserve membership, and yet, as indicated in Table I, many of the banks in the smaller size groups are members of the Federal Reserve. Access to the Federal Reserve services discussed above does not provide sufficient benefits to offset the opportunity costs of required reserves. Therefore, the remaining

\footnotetext{
${ }^{14}$ The numerator of this ratio is demand balances at conespondents plus CIPC for the following reasons. One reason concerns the differences anong member banks in the way they recond deposits at correspondents. Some banks recond the value of deposits to accounts at correspondents as CIPC until the funds are collected; others record geposits at correspondents as demand balances wher they make deposits, whether the funds wil] be available for their to immediately or in a few days. Therefore, adding CIPC to demand balances at correspondents is necessary for getting comnable observations among banks. Member banks that clear checks thongh their Reserve Banks are required to record moncollected funds as CIPC. If these banks were nommembers, those CIPC would comt as reserve assets. Therefore, these funds are included in the numerator of the ratio in Table $v$, which shows the extent to which member banks hold donble reserve assets.
}

205es references in footnote 7 . 


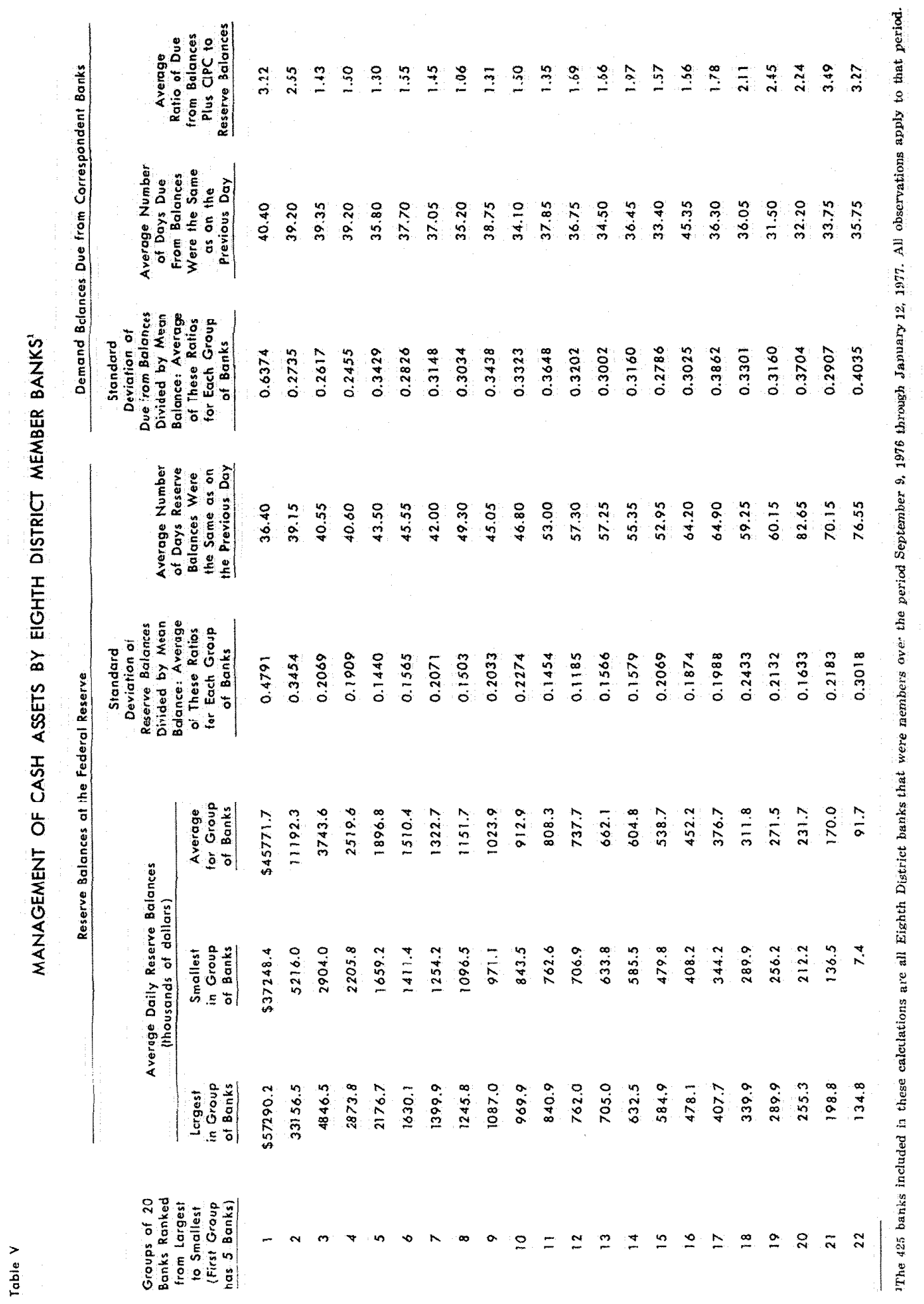


privilege of Federal Reserve membership which appears to account for retention of membership by the smaller banks is access to a lender of last resort through their Reserve Bank's discount window. That privilege is a type of insurance policy on availability to credit during periods of financial difficulty, whether that difficulty occurs within the individual bank or in the whole economy. The cost of membership to a bank can be considered its premium paid for this form of insurance. Since the Federal Reserve has a monopoly on offering the service of lender of last resort, it can charge high premiums for that service, as indicated by the costs of membership calculated above.

\section{Pereer berks}

There remains the question of why most of the larger banks remain in the Federal Reserve. One possible explanation is that the large member banks use enough Reserve Bank services to more than compensate them for the opportunity costs of the reserve balances they hold. Table IV provides information on this explanation. Dividing the cost to the Reserve Bank of providing services to banks in the largest group by their average reserve balances yields an implicit rate of return of only 1.69 percent. For the three largest banks in the survey, that implicit rate of return is 1.83 percent. As noted above, these figures are understated somewhat because the checks sent by some of these banks directly to other Reserve Banks are not accounted for. But even allowing for that factor, the large member banks receive a low rate of return on their reserve balances in terms of the costs of the services they use. However, membership may still be profitable for the large banks if access to Federal Reserve services allows them to eam large profits as correspondent banks.

These results do not support the view that the larger banks retain their membership in the Federal Reserve because of high implicit returns on their reserve balances. There are too few large banks included in the survey of the utilization of services by member banks to draw strong conclusions about the generality of these results or the reasons why the larger banks retain their membership in the Fed. However, it is unlikely that many of the large member banks receive very high implicit rates of return on their reserves in the form of services, since for the Federal Reserve System as a whole the cost of providing services to member banks is approximately one percent of total reserve balances held by members at Reserve Banks. Therefore, the Federal Reserve is effectively imposing a tax on the banking industry, even with Federal Reserve membership being voluntary. The tax takes the form of interest foregone by member banks on their reserve balances less the costs to Reserve Banks of providing services to member banks. At an interest rate of five percent, that tax in 1976 was about $\$ 1$ billion. ${ }^{21}$

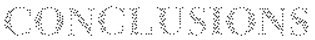

An analysis of the costs and benefits of Federal Reserve membership is incomplete without information on the degree to which member banks use the services provided by their Reserve Banks. Member banks with total assets of less than about $\$ 50$ million make relatively little use of Reserve Bank services, using the services of correspondents instead. There is evidence that the costs of this arrangement to many of the smaller member banks are lower than the costs of managing their reserve accounts if they made fuller use of Reserve Bank services. Member banks making minimal use of Reserve Bank services bear substantial Federal Reserve membership costs, averaging 11.2 percent of profits and 1.8 percent of equity capital for one group of banks.

Most of the major correspondent banks have remained members of the Federal Reserve. The large banks are heavy users of Reserve Bank services, but their implicit returns on reserve balances in the form of services are substantially higher than the implicit returns to the smaller member banks, but are still rather low.

\footnotetext{
2Member bank reserves held at Reserve Banks averaged $\$ 26.2$ billion in 1976. Suppose the opportmity cost to dember banks from holding those reserves is 5 percent, the average yield on U.S. Govermment Treasury bills last year. The cotal opportmity cost of holding reserves would be $\$ 1.3$ sillion. With the total costs to Reserve Banks of offering services to nember banks between $\$ 200$ million and $\$ 300$ millon, the total implicit tax on banking was about \$1 billion.
} 


\section{APPENDIX}

\section{Calculation of the Costs of Federal Reserve Membership}

The purpose of the following calculations is to estimate the income that selected banks forego by being members of the Federal Reserve System. Member banks included in this analysis have the following characteristics:

(a) they clear checks and remit for the Fed's cash letters through correspondents,

(b) they hold no securities in safekeeping, and

(c) none of them are regular borrowers through the discount window, as identified above.

Banks with these characteristics are chosen since becoming a nonmember would have less effect on their operations than on other banks in the survey and because specific dollar amounts can be assigned less arbitrarily to the Reserve Bank services they use than for other banks that make use of additional Reserve Bank services. In total, 54 banks meet these conditions; their total assets range from $\$ 3.4$ million to $\$ 44.5$ million. Only seven of these 54 banks have any demand deposit liabilities due to other commercial banks, averaging $\$ 33$ thousand during the two weeks ending January 12, 1977. These banks do not appear to be functioning as correspondents to any significant degree; therefore, no adjustment is necessary for loss of correspondent banking profits due to these banks becoming nonmembers.

The first step involves estimating how much a bank could increase its earning assets if it became a nonmember (assuming its total assets remain unchanged). Since Illinois has no reserve requirements, member banks in lllinois are assumed to increase their eaming assets by the amount of their average reserve balances at the Reserve Bank. Of the 54 banks in this analysis 35 are located in Illinois.

The calculations are more complex for Missouri banks. Reserve requirements for nonmember banks in Missouri are approximately equal to those of Federal Reserve mem" bers. Nommember banks in Missouri may hold their reserve assets only as vault cash, demand balances at correspondents, or cash items in the process of collection (CLPC). Banks are assumed to have the same average level of vault cash and CIPC whether they are nember or nonmember banks. The reserves necessary to satisfy a bank's state reserve requirements are calculated as its average reserve balance at the Reserve Bank plus its average demand balance at correspondents and CIPC multiplied by the bank's marginal reserve requirements on demand deposits. Under Fed reserve requirements, demand balances at correspondents and CIPC are subtracted in calculating demand deposits subject to reserve requirements, whereas that deduction is not made for nonmember banks in Missouri. If a bank's demand balances at correspondents are larger than what would be required to meet state reserve requirements as a nonmember bank, the bank is assumed to increase its eaning assets by the amount of its current reserve balances at the Fed if it becomes a nonmember. If a bank's demand balances at correspondents are smaller than what would be required to meet state reserve requirements, the amount by which that bank could increase its earning assets is calculated by adding its average reserve balance at the Reserve Bank to its average demand balance at correspondents and subtracting its required reserve balance at correspondents as a nonmember bank. Average daily reserve balances, demand balances at correspondents, and CIPC are measured over the period September 9, 1976, through Januaty $12,1977$.

The income foregone as a nember bank is calculated as follows:

(1) the dollar amounts by which a bank could increase its earning assets as a nonmember is multiplied by five percent.

(2) the following amounts are deducted from that calculated in (1) above:

(a) the anmual cost to the bank of obtaining its coin and currency service as a nonmember bank;

(b) the number of wire transfers the bank makes at an amual rate multiplied by $\$ 2$, the approximate cost of initiating a wire transfer as a nonmember bank;

(c) for banks having their reserve accounts debited and credited for money shipments, the number of such ledger entries in a year charged at ten cents per entry. This amount is approximately the implicit charge by correspondent banks per ledger entry in their account analysis.

Among the 54 banks, the resulting measure of income foregone for ench bank averages 1.8 percent of 1976 equity capital. For the 49 banks with positive profits in 1976 , income foregone as a member of the Federal Reserve averaged 11.2 percent of their 1976 profits. 